\title{
A STATISTICAL ANALYSIS OF TREND OF CHANGE OF EXPANSION OF PORK IN ASSAM
}

\section{BIJU BORAH, ATUL BORGOHAIN, L. SANATHOI KHUMAN \& GAUTAM BORDOLOI}

Department of Extension Education, College of Veterinary Science, Assam Agricultural

University, Khanapara, Guwahati, Assam, India

\begin{abstract}
A study was carried out in four prominent pork markets areas of Assam, which also have a warm hilly weathers condition. Data were collected from a total of 200 pork retailer respondents through a pre-tested, reliable and valid interview schedule. The trend of demand for pork over the last five years increased almost by double and the increase in percentage of average number of pork shops was $65.84 \%$. The trend of pork market was expanded by $50 \%$ and the trend of demand of pork was increased almost by double over the last five years. However, the trend of pork sold per retailer was decreased (42.5\%) over the last five years. The increase in percentage of pork price in between the years 2010 to 2015 and 2005 to 2010 was $41 \%$ and $76 \%$ respectively and the price of pork did not vary in winter, spring and autumn, but it reduced during summer and increased during monsoon and during festive seasons.
\end{abstract}

KEYWORDS: Statistical Analysis, Trend, Change, Expansion, Pork \& Assam

Received: Jan 04, 2018; Accepted: Jan 25, 2018; Published: Feb 13, 2018; Paper Id.: IJESRFEB201810

\section{INTRODUCTION}

In Assam, the pork and its produces are in demand, their dominance has been increasing over time and they are integral to our very system of community life; marketing plays an important role in their supply, price, transport, availability etc. The state has a pork marketing scenario which projects a very poor self-sufficient image because demand for pork is so high whereas, local production cannot suffice the actual demand (Payenget al. 2013). In order to understand the pork market; to determine the current and future needs and preference, attitude and behavior of the consumers; and to assess changes in the business environment that may affect the size and the nature of market in future, the market intelligence is required that can provide a sustainable future market to fill in the gap between the demand and supply of pork in Assam (Shyam2015).

\section{MATERIALS AND METHODS}

An investigation was undertaken in four prominent pork markets areas of Assam i.e. Dhemaji, KarbiAnglong, Kamrup and Tamulpur. From these pork market areas, 50 numbers of pork retailers from each area were randomly selected, making the total sample size of 200. For our generalization, we assumed that the pork market of Assam was representing by these four pork market areas to fulfill the objectives. Data for various relevant aspects were collected through a pre-tested, reliable and valid interview schedule. The data thus collected were scored, compiled and tabulated as per the established norms and procedures and were subjected to appropriate statistical analysis (Frequency percentage and Pearson's Correlation) in order to arrive at a conclusion in respect of the set objective. 


\section{RESULTS AND DISCUSSIONS}

\section{Increase in Percentage of Average Numbers of Pork Shops}

Table 1 exhibited that, five years back, the average numbers of pork shop was around 2 nos. and their corresponding figures after 5 years was 4 nos. The increase in percentage of average number of pork shops was found to be $65.84 \%$. The reasons for the present findings might be due to increase in human population growth, increase in pork and pork products demand by the traditional and non-traditional pork consumers and more preference of pork than other available meat. Moreover, majority of the tribal people of Assam, traditionally consumed pork and besides that, in many occasions, ceremonies and festivals, preference of pork is at first. And due to high demand of pork and its product, the increase in numbers of pork retailer and pork shop was obvious. The present findings received support from the findings of Payeng et al. (2013) and Pegu (2014).

Table 1: Increase in Percentage of Average Number of Pork Shops

\begin{tabular}{|l|c|c|c|}
\hline \multicolumn{1}{|c|}{ Area } & $\begin{array}{c}\text { Present Avg. Nos. } \\
\text { of Pork Shop }\end{array}$ & $\begin{array}{c}\text { 5 Years Back Avg. } \\
\text { Nos. of Pork Shop }\end{array}$ & $\begin{array}{c}\text { Increase in } \\
\text { Percentage (\%) }\end{array}$ \\
\hline Dhemaji $(\mathrm{n}=25)$ & $3.68(2-6)$ & $2.2(1-3)$ & 67.27 \\
\hline KarbiAnglong $(\mathrm{n}=25)$ & $3.72(3-5)$ & $2.24(2-3)$ & 66.07 \\
\hline Kamrup $(\mathrm{n}=25)$ & $4.84(2-7)$ & $2.76(1-5)$ & 75.36 \\
\hline Tamulpur $(\mathrm{n}=25)$ & $3.88(3-6)$ & $2.52(2-5)$ & 54.00 \\
\hline Pooled $(\mathrm{n}=100)$ & $4.03(2-7)$ & $2.43(1-5)$ & 65.84 \\
\hline
\end{tabular}

**Figures in parentheses indicate ranges.

\section{Transition in Pork Market}

Table 2 showed that, the majority of the respondents reported that the trend of pork market expansion over the last five years was increased by $50 \%$. The reason might be due to high demand of pork and its product, rapid urbanization, increase in income and popularization of pork among caste Hindu societies and so, because of these factors, the change in pork market expansion is obvious. These findings received support from the study of Shyam (2011) and Payeng et al. (2013).

Table 2 also indicated the, the majority of the respondents reported that the trend of demand for pork over the last five years was increased almost by doubled over the last five years. This could be mainly due to the fact that there might be an increase in the pork consumption by the existing consumers and non-traditional pork consumers in both rural and urban areas. Similar findings were also reported by Wright et al. (2010), Shyam (2011)and Payenget al. (2013).

Further, from Table 2, it was found that the majority of the respondents reported that the trend of quantity of pork sold over the last five years was decreased. This might be due to the fact that with the expansion of pork and other meat markets there is some diminishing effect on retailing of pork due to upsurge competition. These findings received support from Shyam (2011), Johari (2013) and Imchen (2014).

Table 2: Distribution of Respondents on the Basis of Transitions in Pork Market

\begin{tabular}{|l|c|c|c|c|c|c|}
\hline \multirow{2}{*}{ Area } & \multicolumn{5}{|c|}{ Transitions In Pork Market } \\
\cline { 2 - 7 } & Double & $\begin{array}{c}\text { Almost } \\
\text { Doubled }\end{array}$ & $\begin{array}{c}\text { Increased by } \\
\text { 50 Per Cent }\end{array}$ & $\begin{array}{c}\text { Somewhat } \\
\text { Increase }\end{array}$ & $\begin{array}{c}\text { Same } \\
\begin{array}{c}\text { Decrease } \\
\text { d }\end{array}\end{array}$ \\
\hline Trend of Pork market expansion & $28(14)$ & $71(35.5)$ & $93(46.5)$ & $8(4)$ & $0(0)$ & $0(0)$ \\
\hline Trend of demand for pork & $38(19)$ & $70(35)$ & $66(33)$ & $26(13)$ & $0(0)$ & $0(0)$ \\
\hline Trend of pork sold per retailer & $0(0)$ & $0(0)$ & $24(12)$ & $74(37)$ & $17(8.5)$ & $85(42.5)$ \\
\hline
\end{tabular}


**Figures in parentheses indicate percentage.

\section{Trend of Price Variation Over Time}

Table 3 revealed that, the trend of price variation over time increased tremendously during the couple of years. It was clearly seen that in 2005-06 the price of pork was Rs.65 and by 2014-15 it reached Rs.187.50. There was also an increased in percentage of price by $41 \%$ and $76 \%$ in between the years 2010 to 2015 and 2005 to 2010 respectively. These could be mainly due to the fact that the price of pork was found to be increasing at an accelerated rate due to high demand of pork, shortage of pork supply and involvement of middle men in the marketing channel. Therefore, strategies and policies need to be formulated by the Govt. to fill in the gap between the demand and supply of pork and to eliminate the middle men from the marketing channel. Similar findings were also reported by Johari (2013) and Shyam (2015).

Table 3: Trend of Price Variation Over Time (Rs.)

\begin{tabular}{|c|c|c|c|c|c|}
\hline \multirow{2}{*}{ Yreas } & \multicolumn{5}{|c|}{ Trend of Price Variation Over Time (Rs.) } \\
\cline { 2 - 6 } & Dhemaji & Karbianglong & Kamrup & Tamulpur & Pooled \\
\hline $\mathbf{2 0 1 4 - 1 5}$ & 200.00 & 160.00 & 240.00 & 150.00 & 187.50 \\
\hline $\mathbf{2 0 1 3 - 1 4}$ & 180.00 & 160.00 & 220.00 & 130.00 & 172.50 \\
\hline $\mathbf{2 0 1 2 - 1 3}$ & 160.00 & 140.00 & 200.00 & 130.00 & 157.50 \\
\hline $\mathbf{2 0 1 1 - 1 2}$ & 160.00 & 140.00 & 180.00 & 120.00 & 150.00 \\
\hline $\mathbf{2 0 1 0 - 1 1}$ & 140.00 & 120.00 & 160.00 & 110.00 & 132.50 \\
\hline $\mathbf{2 0 0 9 - 1 0}$ & 120.00 & 110.00 & 140.00 & 90.00 & 115.00 \\
\hline $\mathbf{2 0 0 8 - 0 9}$ & 110.00 & 90.00 & 120.00 & 80.00 & 100.00 \\
\hline $\mathbf{2 0 0 7 - 0 8}$ & 100.00 & 80.00 & 120.00 & 70.00 & 92.50 \\
\hline $\mathbf{2 0 0 6 - 0 7}$ & 90.00 & 80.00 & 100.00 & 60.00 & 82.50 \\
\hline $\mathbf{2 0 0 5 - 0 6}$ & 70.00 & 60.00 & 80.00 & 50.00 & 65.00 \\
\hline \multicolumn{7}{|c|}{ Increase in Percentage Over 5 Years (\%) } \\
\hline $\mathbf{2 0 1 0 - 1 5}$ & 43.00 & 33.00 & 50.00 & 36.00 & 41.00 \\
\hline $\mathbf{2 0 0 5 - 1 0}$ & 71.00 & 83.00 & 75.00 & 80.00 & 76.00 \\
\hline
\end{tabular}

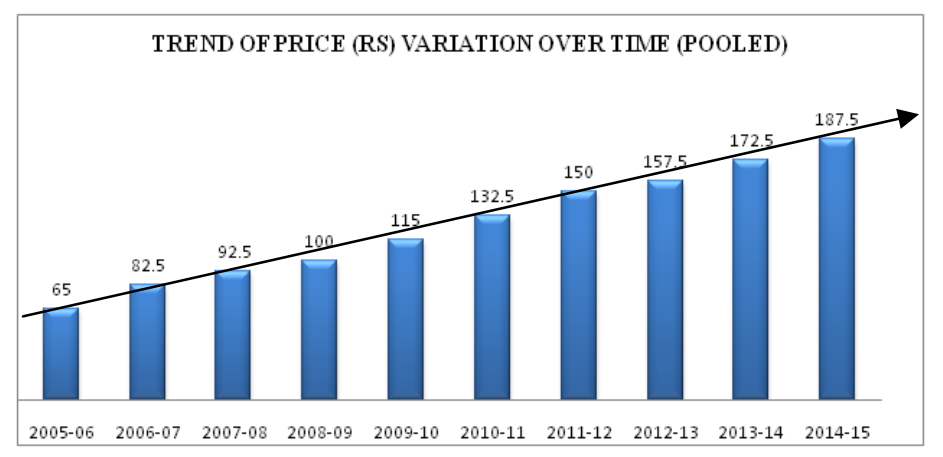

Figure 1: Trend of Price Variation Over Time (Pooled)

\section{Trend of Price Variation Over Season}

Table 4 depicted that, there was variation in the price of pork in different seasons. It could be explained by the fact that due to less supply of pork during monsoon season due to flood and poor road connectivity hike in the price of pork is obvious. Moreover, during summer the consumption of pork was found to be less and because of that there use to be less demand of pork during time. However, the price of pork was found to be increased during festive season due to high demand of pork during that season. Govt. should established some pig breeding farms and slaughtering units in the state to 
maintained a stock population to minimized the price variation over seasons. The findings were similar to the studies of Johari (2013) and Haque (2015).

Table 4: Trend of Price (Rs) Variation Over Season

\begin{tabular}{|l|c|c|c|c|c|}
\hline \multirow{2}{*}{ Season } & \multicolumn{5}{c|}{ Trend of Price Variation Over Season (Rs.) } \\
\cline { 2 - 6 } & Dhemaji & Karbianglong & Kamrup & Tamulpur & Pooled \\
\hline Winter & 200 & 160 & 220 & 150 & 182.5 \\
\hline Spring & 200 & 160 & 220 & 150 & 182.5 \\
\hline Summer & 180 & 160 & 220 & 140 & 175.0 \\
\hline Monsoon & 220 & 160 & 220 & 150 & 187.5 \\
\hline Autumn & 200 & 160 & 220 & 150 & 182.5 \\
\hline Festive season & 200 & 160 & 240 & 150 & 187.5 \\
\hline
\end{tabular}

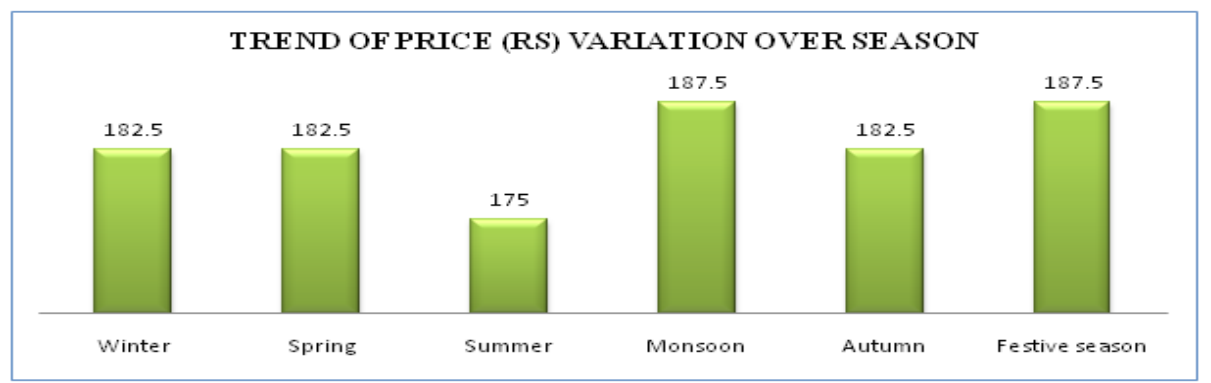

Figure 2: Trend of Price (Rs) Variation Over Season (Pooled)

Correlation Between Trend of Pork Market Expansion, Trend of Demand of Pork, Trend of Pork Sold Per Retailer, Price Variation Over Time and Season

Table 5 indicated that the trend of Pork market expansion is the determinant of demand for pork in the market, trend of price variation over time and trend of price variation over season. Similarly trend of demand for pork is also a determinant of trend of pork sold per retailer, trend of price variation over time and trend of price variation over season. Therefore, a positive correlation between them is expected. However, trend of Pork market expansion over the last 5 years had negative and highly significant $(\mathrm{p}<0.01)$ correlation with trend of pork sold per retailer $[\mathrm{r}=-0.74 * *$. With an expansion of pork market, it has some diminishing effect on retailing due to increased competition with other pork retailer in those respective areas. Therefore a negative correlation is justified. This finding was in conformity with that of Johari (2013).

Table 5: Correlation Between the Variables

\begin{tabular}{|l|c|c|c|c|c|}
\hline \multicolumn{1}{|c|}{$\begin{array}{c}\text { Pearson's Correlation } \\
\text { Between the Variables }\end{array}$} & $\begin{array}{c}\text { Trend of } \\
\text { Pork Market } \\
\text { Expansion }\end{array}$ & $\begin{array}{c}\text { Trend of } \\
\text { Demand } \\
\text { For Pork }\end{array}$ & $\begin{array}{c}\text { Trend of } \\
\text { Pork Sold } \\
\text { Per Retailer }\end{array}$ & $\begin{array}{c}\text { Trend of Price } \\
\text { Variation Over } \\
\text { Time }\end{array}$ & $\begin{array}{c}\text { Trend of Price } \\
\text { Variation Over } \\
\text { Season }\end{array}$ \\
\hline $\begin{array}{l}\text { Trend of Pork market } \\
\text { expansion }\end{array}$ & - & $0.34^{* *}$ & $-0.74 * *$ & $0.42^{* *}$ & $0.20^{*}$ \\
\hline Trend of demand for pork & $0.34 * *$ & - & $0.25^{* *}$ & $0.51 * *$ & $0.32 * *$ \\
\hline
\end{tabular}

**significant at 1 per cent level of probability

*significant at 5 per cent level of probability 


\section{SUMMARY AND CONCLUSIONS}

The increase in percentage of average number of pork shops was found to be $65.84 \%$. The change of pork market expansion was increased by $50 \%$ and the trend of demand for pork over the last five years was increased almost by doubled. There was also an increased in percentage of price by $41 \%$ in between the years 2010 to 2015 . Although, there is steep price hike of pork still, in the rise of urbanization and remarkable economic growth there also has been an immense rise in the demand of quality pork which has also paved a way for employment generation for the unemployed youth in the rural areas by pig and pork production. Therefore, strategies and policies need to be formulated by the Govt. and also the market intelligence is required that can provide a sustainable future market to fill in the gap between the demand and supply of pork.

\section{ACKNOWLEDGEMENT}

The authors are also thankful to the Dean and Director Research (Vety.) Assam Agricultural University, Khanapara Campus, Guwahati-22, Govt. of Assam for their necessary help and facilities provided during this study. We are also thankful to the market committee of the surveyed areas of Assam for facilitating suitable and accurate market data.

\section{REFERENCES}

1. Wright, A., Deka, R., Thorpe, W. and Lapar M. L. 2010. Sustainable Land Use and Rural Development in Mountainous Regions of Southeast Asia, International symposium on the pig sector in North East India: status, constraints and opportunities, Hanoi, 21-23 July 2010.

2. Shyam, J. 2011. A study on the entrepreneurial behavior of pig farmers in Kamrup district of Assam. M. V. Sc. Thesis, College of Veterinary Science, Assam Agricultural University, Guwahati, Assam, India.

3. Johari, M. 2013. System of rearing and marketing of pig in DimaHasao district of Assam. MVSc Thesis, College of Veterinary Science, Assam Agricultural University, Guwahati, Assam, India.

4. Lounaci Zohra, Doumandji Salaheddine, Doumandji-Mitiche Bahia \& Berrouane Fatma Zohra, Dipterans Biodiversity of Agricultural and Medico Veterinary Interest in The Marsh of Reghaia (Algeria), International Journal of Zoology and Research (IJZR), Volume 4, Issue 5, Spetember - October 2014, pp. 71-82

5. Payeng, S.,Borgohain, A. and Bora, J. R. 2013. Economics of pig production in organized and unorganized sectors. Indian Res. J. Ext. Edu., 13 (1) : 101-106.

6. Imchen, I. 2014. Meat marketing patterns in Kohima district of Nagaland. MVSc Thesis, College of Veterinary Science, Assam Agricultural University, Guwahati, Assam, India.

7. Pegu 2014. Piggery Entrepreneurship in Dhemaji district of Assam. M. V. Sc. Thesis, College of Veterinary Science, Assam Agricultural University, Guwahati, Assam, India.

8. R. P. Diwakar et al., Current Update on Canine Parvovirus in Veterinary Field Aspect, International Journal of Zoology and Research (IJZR), Volume 4, Issue 5, September - October 2014, pp. 71-82

9. Haque, M. 2015. Merchandising and consumption behaviour of animal husbandry produces and products in Assam. M. V. Sc. Thesis, College of Veterinary Science, Assam Agricultural University, Guwahati, Assam, India.

10. Shyam, J. 2015. Contribution of Backyard Pig production system in the Livelihood of schedule Tribes families of Assam. Ph.DThesis, Deemed University, IVRI, Izatnagar, U.P. 
